UDC: $616.92 / 93-595.421: 579.61$

\title{
NATURAL FOCI OF LYME-BORRELIOSIS IN LVIV REGION: RESULTS OF ACAROLOGICAL OBSERVATIONS AND LABORATORY DIAGNOSTICS
}

\author{
A. M. Shulhan', O. Z. Zarichna', I. M. Lozynskyy', O. B. Semenyshyn ${ }^{2}$ \\ ${ }^{1}$ Research Institute of Epidemiology and Hygiene \\ of Danylo Halytsky Lviv National Medical University \\ 12, Zelena St., Lviv 79005, Ukraine \\ ${ }^{2}$ GA "Lviv Regional Laboratory Centre Ministry of Health of Ukraine" \\ 27, Krupyarska St., Lviv, 79013, Ukraine \\ e-mail: olha_zar@i.ua
}

Shulhan A. M., Zarichna O. Z., Lozynskyy I. M., Semenyshyn O. B. Natural foci Lime-borreliosis in Lviv region: results of acarological observations and laboratory diagnostics. Studia Biologica, 2019: 13(1); 85-94 • DOI: https://doi.org/10.30970/sbi.1301.586

A spectrum of the main carriers of Lyme-borreliosis pathogens was determined, their activity and epidemic significance were studied in natural areas of Lviv region. Taking into account that the situation with tick-borne infections depends on the dynamics of the number of ticks, carrying out acarological monitoring allows to detect changes in the state of natural foci in a timely manner. The territory of Lviv region is characterized by a substitution in certain biotopes of Ixodes ricinus populations on Dermacentor reticulatus - a species more tolerant to changing environmental conditions, and in general displacement of the boundaries of these two species. A direct correlation between the average strength and the number of $I$. ricinus ticks was established. That confirmed a position that in the natural foci of borreliosis the main role in circulation of pathogens is still played by this species. The average infection rate of Ixodide by the pathogen in Lviv region during the 2012-2014 season is fully consistent with the indicators for the active natural foci of this infection. Preliminary data were obtained on the inclusion of $D$. marginatus in a circulation circle of mites, until recently, their involvement in the transmission of Lyme-borreliosis agents was unknown. A study of distribution and ecological characteristics of $I$. ricinus, $D$. reticulatus, $D$. marginatus in natural and anthropogenic cenosis is necessary both for predicting possible formation of natural foci and for improving a strategy and tactics of the anti-acaricidal measures.

Keywords: Ixodic ticks, Lyme-borreliosis, natural foci

(C) 2019 M. P. Lutska. Published by the Ivan Franko National University of Lviv on behalf of Біологічні Студії / Studia Biologica. This is an Open Access article distributed under the terms of the Creative Commons Attribution License (http://www.budapestopenaccessinitiative.org/ and Creative Commons Attribution 4.0 License), which permits unrestricted reuse, distribution, and reproduction in any medium, provided the original work is properly cited.

ISSN 1996-4536 (print) • ISSN 2311-0783 (on-line) • Біологічні Студії / Studia Biologica • 2019 • Том 13/№1 • С. 85-94 


\section{INTRODUCTION}

In the countries bordering Ukraine, over the past decades the boundaries of habitats of Ixodic ticks have changed significantly. In addition, the researchers described the substitution of independent populations of some species by other, environmentally close $[3,12]$. One cannot exclude such processes in the landscapes of the Western region of Ukraine, in particular the Lviv region, because of its natural conditions extending to the neighboring territories, while the ixodofauna is represented by the same species of ticks, the same with their zoogeography and chorological structure of the populations. Lviv Oblast is located within the Volynska and Podilska Highlands, it is located in three natural zones: the forest, the forest-steppe and the Carpathian zone. Probably, a progressive transformation of landscapes, in particular, the intensive development of forest areas of Lviv region, and global climate change, could have contributed to changes in the Ixodide population. In recent years, there has been an increase in number of ticks in the forest massifs surrounding the city. The active process of urbanization has led to the fact that the natural foci of infections are located within the settlements, that increases the incidence of tick-borne infections, in particular, Lyme-borreliosis (LB) among the urban residents.

In 2017-2018, in Lviv region, in comparison with previous years, the epidemic situation of tick borelliosis has deteriorated sharply. The incidence rate increased from 3.13 per 100 thousand population in 2012 to 12.32 in 2017 , and to 12.87 in 2018 . The level of spontaneous infection of borrelia in Ukraine in 2017 increased 2.1 times, that led to a new cycle of increasing the incidence [8]. In 2017, in the study of ticks removed from humans (407 ticks), $24.3 \%$ of positive results were detected, in 2018 - 420 cases, $23.8 \%$ of which were found positive.

Among modern methods of diagnosis of LB, along with the epidemiological features and clinical picture of this disease, serological tests can be distinguished: the reaction of indirect immunofluorescence (IFA) and molecular genetic - real time polymerase chain reaction (PCR). Investigation of the infection of borrelia by the microscopy method is a promising method, whose use allows tracing the pathogen circulation in the population of carriers, that is important for assessing the epidemiological situation in a separate region of study. Taking into account that the situation with tick-borne infections depends on a dynamics of the number of ticks, acarological monitoring allows timely detection of changes in the state of natural foci. Its results serve a basis for prediction of trends in epizootic and epidemic processes, planning and implementation of optimal measures for prevention of the diseases in the population.

The aim of our work was to determine a spectrum of the main carriers of LB pathogens, study their activity and epidemic value in natural foci of Lviv region.

\section{MATERIALS AND METHODS}

Weekly surveys in 2012-2014 from March to November were carried out according to commonly used methods [1, 6, 7]. Ixodid ticks were collected on the flag, the numbers were expressed in terms of number of copies per $1 \mathrm{flag} / \mathrm{km}$. The ticks were identified by the indicator of N.A. Philipova [12]. Filled "on a flag" and determined species composition of 11,190 specimens of ticks (imago, nymph and larvae): 7,912 ticks I. ricinus, 3,080 ticks $D$. reticulatus and 198 ticks $D$. marginatus. 290 flags/km passed, 419 flags/hours

ISSN 1996-4536 (print) • ISSN 2311-0783 (on-line) • Біологічні Студії / Studia Biologica • 2019 • Том 13/№1 • C. 85-94 
on routes were worked out. The material was collected in 16 districts of Lviv region and Lviv city on the territory of 3 landscape and geographical zones: forest (Brodivskyi, Zhovkivskyi, Radekhivskyi, Sokalskyi, Yavorivskyi, Buskyi, Kamyanko-Buzkyi districts), forest-steppe (Gorodotskyi, Zhydachivskyi, Zolochivskyi, Pustomytivskyi, Sambirskyi districts, Lviv), the Ukrainian Carpathians (Drohobytskyi, Stryiskyi districts).

Collection, initial processing, sorting, storage and delivery of material for research werecarried out in accordance with the requirements of the State Sanitary Rules 9.9.5.035-99 "Safety of work with microorganisms of the I-II groups of pathogenicity" (Kyiv, 1999) [7].

For analysis of the ecological and faunistic data, the indicators proposed by V.M. Beklemishev were used. [2]: the abundance index is the average number of ticks per record (flag/hour), the index of domination - the ratio of the number of individuals of one species to the total number (in \%) of species in biocenosis, occurrence index - the number of samples in which the individuals of the investigated type, expressed in $\%$ of the total number of analyzed samples.

Antibodies against LB pathogens [4] were detected by the indirect IFA using commercial preparations for luminescent microscopy (Scientific Research Institute of Epidemiology and Microbiology named after M.F. Gamaleya, Russian Federation).

A real-time PCR method was used to detect 16S rRNA of Borrelia burgdorferi sensu lato using the AmliSens Borrelia burgdorferi sensu lato-FL (Russian Federation) diagnostic test systems. The results were recorded on the Rotor-Gene ${ }^{\mathrm{TM}} 6000$ amplifier with the Thermal Cycler System software.

For statistical processing of the indicators, commonly used methods of variation statistical analysis using "Statistica 8.0" program [5] were used.

\section{RESULTS AND DISCUSSION}

In a season of 2012-2014, the index of $I$. ricinus dominance in the gatherings in various biotopes comprised from $20.4 \%$ to $97.5 \%$, were dominant only in the foreststeppe area $-52.7 \pm 0.6 \%$, and in the forest zone $-D$. reticulatus, respectively, $47.4 \pm 0.9 \%$ (Table 1). A difference in number of two backgrounds of Ixodide in different landscape zones was minimal ( $p>0.05)$.

Taking into account a decisive influence of temperature indices on the activity of Ixodic ticks (Table 2), it can be argued that weather conditions of 2012-2014 season were generally favorable for all phases of development of Ixodic ticks. In 2012 and 2014, the activation of imago ticks I. ricinus occurred in the first three decades of March, with a transition of daytime temperature through $5-7^{\circ} \mathrm{C}$. On the territory of Stryiskyi park in the city of Lviv, the first cases of suction imago mites to humans and animals (dogs) are registered in March 7-12. In 2013, the biological minimum of the average daily air temperature (transition through $+5^{\circ} \mathrm{C}$ ) in different soil-climatic zones of the region was observed for 10 to 14 days later than the average long term - during April 11-14 (11.04 - central and northern regions, 13-14.04 - in the foothills).

During the environmental monitoring in 2012-2014, spring maximum of numbers (33.8 \% of the total number of captured individuals) in the control stations of Lviv region was I. ricinus falling for April-May with a peak in May (Fig. 1). After a slight depression in July-August, a second peak in number of Ixodid was observed in September-October.

ISSN 1996-4536 (print) • ISSN 2311-0783 (on-line) • Біологічні Студії / Studia Biologica • 2019 • Том 13/№1 • С. 85-94 
The autumn activity wave $I$. ricinus in total for three years of observations amounted to $37.2 \%$ of total number of ticks collected during the season. A difference between the peaks of spring $(19.8 \%)$ and autumn $(25.4 \%)$ activity of $I$. ricinus was $5.6 \%$.

Table 1. A number of background species of Ixodic ticks in castings in the territory of Lviv region in 2012-2014 season

Таблиця 1. Чисельність фонових видів іксодових кліщів у відловах на території Львівської області у сезон 2012-2014 років

\begin{tabular}{|l|c|c|c|c|c|}
\hline \multirow{2}{*}{ Species of ticks } & \multirow{2}{*}{ Total caught } & \multicolumn{2}{c|}{ Forest zone } & \multicolumn{2}{c|}{ Forest-steppe zone } \\
\cline { 3 - 7 } & 7912 & 3739 & $47.3 \pm 0.6$ & 4173 & $52.7 \pm 0.6$ \\
\hline Ixodes ricinus & 3080 & 1461 & $47.4 \pm 0.9$ & 1619 & $52.6 \pm 0.9$ \\
\hline Dermacentor reticulatus & 198 & 9 & $4.5 \pm 1.5$ & 189 & $95.5 \pm 1.5$ \\
\hline D. marginatus & 11190 & 5209 & $46.6 \pm 0.5$ & 5981 & $53.4 \pm 0.5$ \\
\hline Total & & & & &
\end{tabular}

Table 2. Indicators of climatic factors associated with survival and activity of Ixodes ricinus ticks

Таблиця 2. Показники кліматичних чинників, пов'язаних із виживанням і активністю кліщів Ixodes ricinus

\begin{tabular}{|c|c|c|c|c|}
\hline \multirow{2}{*}{$\begin{array}{l}\text { Phases (stages) } \\
\text { of development }\end{array}$} & \multicolumn{3}{|c|}{ Temperature thresholds } & \multirow[t]{2}{*}{ Humidity } \\
\hline & vital minimum & temperature threshold of air & vital optimum & \\
\hline $\begin{array}{l}\text { Larva } \\
\text { Nymph } \\
\text { Imago }\end{array}$ & $\begin{array}{c}-5--7{ }^{\circ} \mathrm{C} \\
\text { no data } \\
-20^{\circ} \mathrm{C} \\
-20{ }^{\circ} \mathrm{C}\end{array}$ & $\begin{array}{c}\text { no data } \\
4^{\circ} \mathrm{C} 5^{\circ} \mathrm{C} \\
4-5^{\circ} \mathrm{C} 7^{\circ} \mathrm{C}\end{array}$ & $\begin{array}{l}15-27^{\circ} \mathrm{C} \\
10-22{ }^{\circ} \mathrm{C} \\
18-25^{\circ} \mathrm{C}\end{array}$ & $80-85 \%$ \\
\hline
\end{tabular}

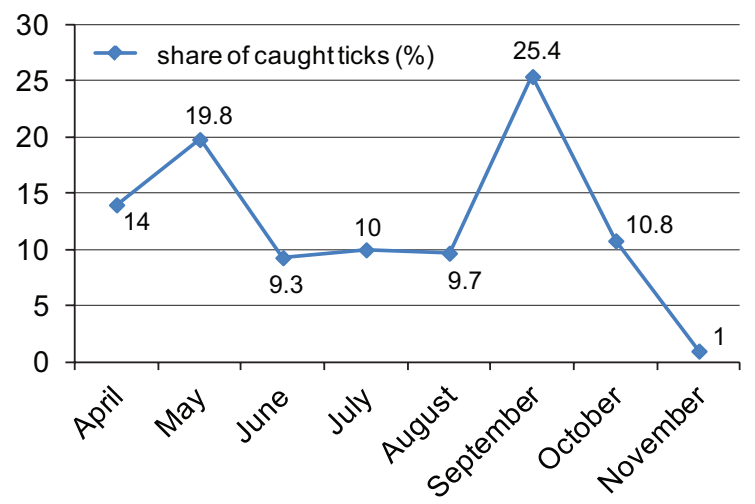

Fig. 1. Dynamics of total number (index of dominance) (\%) Ixodes ricinus in gatherings at control hospitals in Lviv region in 2012-2014 season

Рис. 1. Динаміка сумарної чисельності (індекс домінування) (\%) Ixodes ricinus у зборах на контрольних стаціонарах Львівської області в сезон 2012-2014 років

ISSN 1996-4536 (print) • ISSN 2311-0783 (on-line) • Біологічні Студії / Studia Biologica • 2019 • Том 13/№1 • С. 85-94 
Seasonal number of ticks over years varied in wider limits, but in general, its dynamics was stable. Nymphs on vegetation and on animals appeared in the first decade of April. Their numbers slowly increased during May-July. We did not observe "Classic" maximum of their parasitization in June and the first expressed peak of activity in MayJune. In contrast, for the nymph $I$. ricinus, the maximum number of nymphatic hemipopulations of ticks is a "key" link that is characteristic of the I. ricinus nymph, that ensures an existence of the parasitic LB systems, not only in the Eurasia but also in the USA [15], - was observed in September and amounted to $42.4 \%$ of number of specimens collected for the whole period of observation. Judging by the obtained data, the mass exodus of the nymph in autumn is associated with mating of the larvae that was successfully fed in the first half of summer. The activation of these nymphs is supposedly expected in spring of the next year, that is, a second year from the beginning of the development cycle. Thus, the nymphal stage of ticks development is the basis of significant autumn I. ricinus, and in some years (2012) it was supplemented by males. A total number of females in spring (April-May) was only slightly lower in autumn (August-September) only in 2014, and in 2012-2013 totally exceeded it.

The spring and autumn indices of the abundance of $I$. ricinusimago were almost identical, on average 26.0 (April-June) and 24.1 (August-October) specimens ticks per $1 \mathrm{flag} / \mathrm{km}$. The most recent term for the sucking of ticks to humans is November 11 , 2014, detection of ticks in natural biotopes - November 24 (village Rokitno-Bukovyna Yavorivskyi district and village Obroshino Pustomytivskyi district).

The level of contamination with pathogens is the most demonstrative indicator of the epidemic danger of the territory (natural foci), its assessment in different regions has an important epidemiological and epizootic significance.

In 2012-2014 season, the average infection rate of Ixodide by the LB agent in Lviv region was $9.5 \pm 0.5 \%$ in the forest zone and $11.8 \pm 0.7 \%$ in the forest-steppe biotopes, that fully corresponds to $10.0 \%$ and is higher for active natural foci of this infection (Table 3).

Estimation of a degree of infectivity of various types of ticks confirmed an increasing role of $D$. reticulatus as a sympathizer of the $B$. burgdorferi parasitic system: $10.1 \pm 1.2 \%$ of these isoxidids in the forest and $14.4 \pm 2.0 \%$ in the forest-steppe zones contain a causative agent. The maximum indices of natural infestation of the meadow borer was found in Kamyanko-Buzkyi (18.0 \%), Pustomytivskyi (18.2 \%) districts and in the city of Lviv (22.1\%) (Fig. 3).

Maximum number of the infected $I$. ricinus was caught in Stryiskyi (36.4\%), Buskyi (20.0\%), Brodivskyi (18.5\%) districts and Lviv city (17.0\%) of known enzootic territories with a respect to LB. A direct correlation of the average strength established between the number and infection of ticks $I$. ricinus $(p<0.05)$ confirms a position that, this species plays a major role in natural foci of the LB in a circulation of pathogens.

All positive results obtained with indirect IFA method were confirmed by real time the PCR in a specific DNA region of $B$. burgdorferi s.I. found in all samples of ticks.

In seasonal dynamics, the average annual infestation of I. ricinus female bovine animals in control stations of Lviv region ranged from $15.3 \%$ in April, $14.6 \%$ in May to $10.4 \%$ in June. In July-August, the highest infection rate was observed $-18.7 \%$ and $20.4 \%$, respectively. In autumn, this level dropped to $11.8 \%$ in September and $8.8 \%$ in October. The infection of the $I$. ricinus nymph was registered from April to October, the maximum was recorded in May and September $-21.2 \%$ and $15.6 \%$, respectively (Fig. 2).

ISSN 1996-4536 (print) • ISSN 2311-0783 (on-line) • Біологічні Студії / Studia Biologica • 2019 • Том 13/№1 • С. 85-94 
Table 3. Natural contamination of Ixodic ticks with pathogens of Lyme-borreliosis on the territory of Lviv region in 2012-2014 seasons

Таблиця 3. Природна зараженість іксодових кліщів збудниками Лайм-бореліозу на території Львівської області у сезони 2012-2014 років

\begin{tabular}{|l|l|c|c|c|}
\hline \multicolumn{1}{|c|}{ Species of ticks } & \multicolumn{1}{|c|}{ Results } & Forest zone & $\begin{array}{c}\text { Forest-steppe } \\
\text { zone }\end{array}$ & $\begin{array}{c}\text { The zone of } \\
\text { the Ukrainian } \\
\text { Carpathians }\end{array}$ \\
\hline Ixodes ricinus & investigated (ticks) & 2221 & 2009 & 41 \\
\hline & positive $(\mathrm{M} \pm \mathrm{m}) \%$ & $9.3 \pm 0.6$ & $11.4 \pm 0.7$ & $14.6 \pm 5.5$ \\
\hline Dermacentor reticulatus & investigated (ticks) & 636 & 313 & 170 \\
\hline & positive $(\mathrm{M} \pm \mathrm{m}) \%$ & $10.1 \pm 1.2$ & $14.4 \pm 2.0$ & $11.2 \pm 2.4$ \\
\hline Together in zones & investigated (ticks) & 2857 & 2322 & 211 \\
\hline & positive $(\mathrm{M} \pm \mathrm{m}) \%$ & $9.5 \pm 0.5$ & $11.8 \pm 0.7$ & $11.8 \pm 2.2$ \\
\hline Total & investigated (ticks) & & 5390 & \\
\hline positive $(\mathrm{M} \pm \mathrm{m}) \%$ & & $10.6 \pm 0.4$ &
\end{tabular}

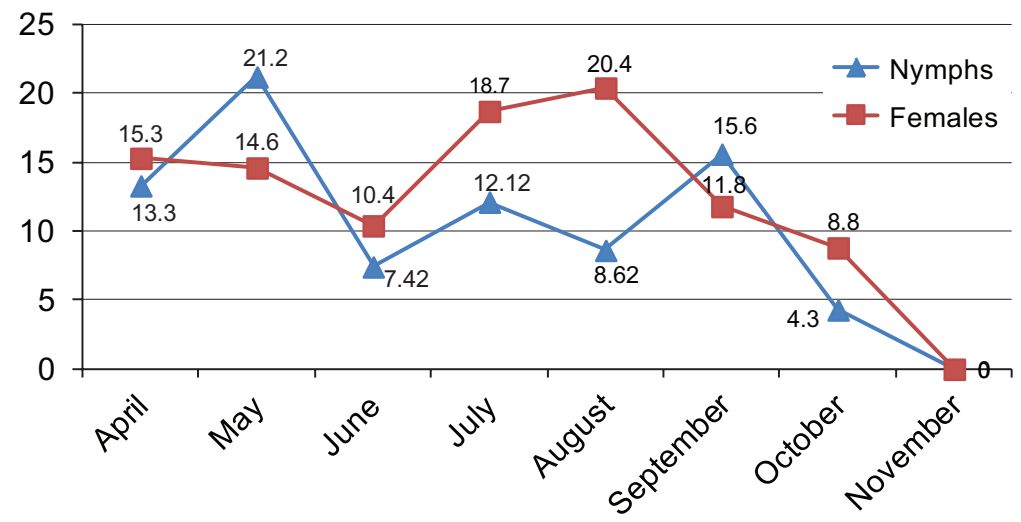

Fig. 2. Dynamics of contamination (\%) of nymphs and Ixodes ricinus females at control stations of Lviv region in 2012-2014 season

Рис. 2. Динаміка зараженості (\%) німф і самок Ixodes ricinus на контрольних стаціонарах Львівської області у сезон 2012-2014 років

A high level of infection (in June - $26.8 \%$ ) should be noted and a potential epidemic value of $I$. ricinus males, that are capable of multiple short-term suction (on one or many vertebrates), and thus - before infection with pathogens LB.

It was found that the seasonal and annual changes in number of $I$. ricinus imago within a specific biotope do not significantly affect the rates of their infestation by Borrelia, and in general, it remains fairly stable. Similar conclusions were obtained for Central Europe [9, 11] and various regions of Russian Federation [10].

ISSN 1996-4536 (print) • ISSN 2311-0783 (on-line) • Біологічні Студії / Studia Biologica • 2019 • Том 13/№1 • С. 85-94 


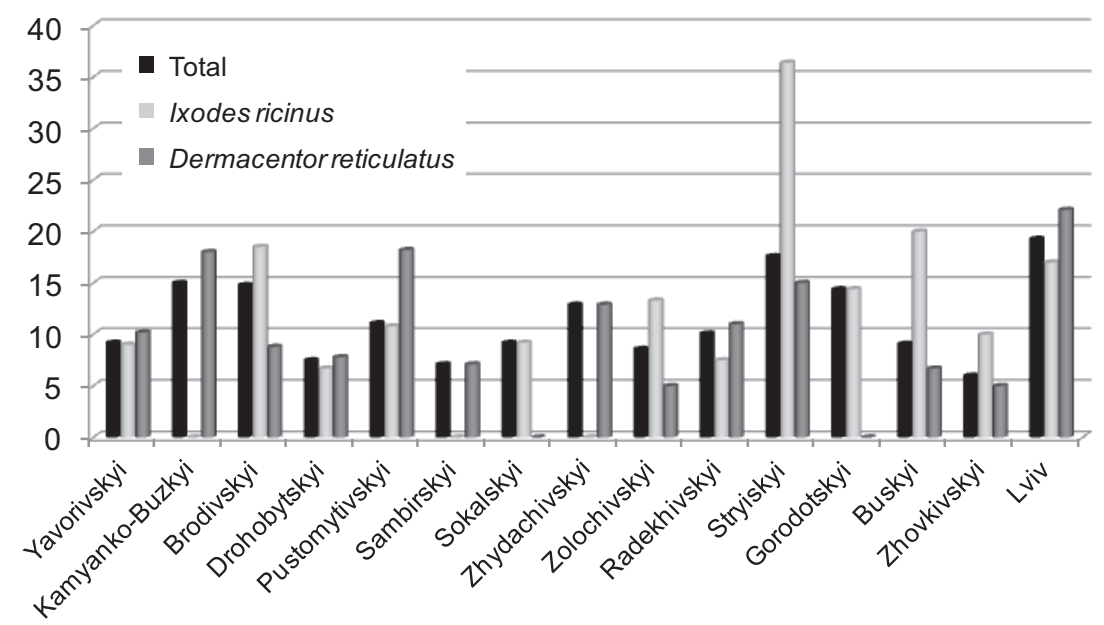

Fig. 3. Natural contamination (\%) of Ixodic ticks caused by Lyme-borreliosis agents in the territory of Lviv region (distribution by regions) in 2012-2014 season

Рис. 3. Природна зараженість (\%) іксодових кліщів збудниками Лайм-бореліозу на території Львівської області (розподіл по районах) у сезони 2012-2014 років

Many researchers point out that specific vectors of Borrelia carriers can be only representatives of the Ixodes genus, and information about an epidemic value of other species of Ixodic ticks or other groups of carriers is considered to be false. In last years, a question of possible epidemic importance of $D$. reticulatus is discussed in Poland, Hungary and other countries $[11,13]$. In our opinion, an increase in number of $D$. reticulatus in our region, that correlates with its infectious pathogen LB $(p<0.05)$, can not be left without attention and requires a special study both from the point of view of the epizootic and possible epidemic significance of this species ticks. The role of $D$. reticulatus in cycles of borrels circulation in natural foci does not raise doubts because the breadwinners of active phases of the development of ticks of this species and $I$. ricinus are the same species of the wildlife. A question of probable epidemic value of $D$. reticulatus is closely linked with the establishment of its aggressiveness towards human and a possibility of transmitting pathogen to them transmissively. The obtained data allow us to talk about the epidemic significance of this type of ticks as a carrier of Borrelia in the surveyed territories.

It should be noted that the evidence of the inclusion of another representative of genus Dermacentor $-D$. marginatus in the circle of borrels has been obtained. Until recently, a participation of $D$. marginatus ticks in the transmission of LB pathogens was unknown. However, based on isolated reports from some European countries [13] and Ukraine - Donetsk, Lugansk and Kharkiv regions, such opportunity should be taken into account [14].

\section{CONCLUSIONS}

1. The territory of Lviv region is characterized by changes in structure of the population of Ixodic ticks - a substitution in certain biotopes of populations I. ricinus on $D$. reticulatus - a species more tolerant to changing environmental conditions, and in general - a displacement of the boundaries of these two species. 
2. The epizootic season for LB transmitted to I. ricinus (imago and nymphs) is significant counting for 9 months and lasts from March to November inclusive. The spring maximum of the number (33.8\% of the total number of individuals caught) I. ricinus fell to April-May with a peak in May.

3. In 2012-2014 season, an average infection rate of Ixodide by the LB agent in the Lviv region was $9.5 \pm 0.5 \%$ in the forest zone and $11.8 \pm 0.7 \%$ in the foreststeppe biotopes, that fully corresponds to the indicators for active natural foci of this infection (10.0\% and above).

4. Presence of a direct correlation between an average strength of number and the infection of ticks $I$. ricinus $(p<0.05)$ confirms a position that in natural foci of borreliosis, the main role in the circulation of pathogens belongs to this species.

5. Preliminary data were obtained on the inclusion of $D$. marginatus in circulation circle of the ticks Borrelia which until recently had not been known to participate in a transmission of LB pathogens.

6. A study of distribution and ecological characteristics of I. ricinus, D. reticulatus and $D$. marginatus in natural and anthropogenic cenoses is necessary both for predicting possible formation of natural foci and improving a strategy and tactics of anti-acaricide measures in order to further increase an effectiveness of population protection, prevention of $L B$, that remains an urgent problem for health care throughout the world.

1. Aristova V.A. Methods of working with blood-sucking ticks - transmitters of arbovirus infections. In: Arboviruses. Moscow, 1986: 69-75. (In Russian)

2. Beklemishev V.N. Terms and concepts required for quantitative accounting of populations of ectoparasites and nicodels. Journal of Zoology, 1961; 40 (2): 148-158. [Google Scholar]

3. Biletska G.V., Lozynskyy I.M., Kurganova I.I. et al. Natural-focal diseases, transmitted by Ixodic ticks in the Western region of Ukraine. Atlas, 2012. 29 p. II. (In Ukrainian)

4. Biletska G.V., Semenyshyn O.B. The method of detecting the pathogen of Lyme disease in Ixodic ticks. Newsletter No. 152-2002. Ukrmedpatentinform Ministry of Health of Ukraine. Kyiv, 2002. 2 p. (In Ukrainian)

5. Borovikov V.P. A popular introduction to the current analysis of data in the STATISTICA system. Moscow: Hotline, 2013. 288 p. (In Russian)

6. Pesenko Yu.V. Principles and methods of quantitative analysis in faunal studies. Moscow: Science, 1982. 286 p. (In Russian)

7. Safety of work with microorganisms of the I-II groups of pathogenicity: Particleboard 9.9.5.035-99. State Sanitary Rules [Effective from 1999-07-01]. Kyiv: Ministry of Health of Ukraine, 1999. 70 p. (In Ukrainian)

8. Nebogatkin I.V., Novokhatny Yu.O., Vidayko N.B. et al. Ixodic tick borreliosis (Lyme disease) in Ukraine (2017). Information and analytical review. Kyiv-Lviv, 2018. 18 p. (In Ukrainian)

9. Chvostáč M., Špitalská E., Václav R. et al. Seasonal patterns in the prevalence and diversity of tick-borne Borrelia burgdorferi sensu lato, Anaplasma phagocytophilum and Rickettsia spp. in an Urban temperate forest in south western Slovakia. International Journal of Environmental Research and Public Health, 2018; 15: 994.

[DOI: https://doi.org/10.3390/ijerph15050994] 
10. Korenberg E.I., Gorelova N.B., Kovalevskii Yu.V. Ecology of Borrelia burgdorferi sensu lato in Russia. Lyme Borreliosis: Biology, Epidemiology and Control. Oxford, CAB International, 2002: 175-200.

[Google Scholar]

11. Kloch A., Mierzejewska E., Karbowiak G., Slivinska K., Alsarraf M., Rodo A., Kowalec M., Dwużnik D., Didyk Y. M., Bajer A. Origins of recently emerged foci of the tick Dermacentor reticulatus in central Europe inferred from molecular markers. Veterinary Parasitology, 2017; 237: 63-69.

[DOI: https://doi.org/10.1016/j.vetpar.2017.02.020; Google Scholar]

12. Rogovskyy A., Batool M., Gillis D.C., Holman P.J., Nebogatkin I.V., Rogovska Y.V., Rogovskyy M.S. Diversity of Borrelia spirochetes and other zoonotic agents in ticks from Kyiv, Ukraine. Ticks and Tick-borne Diseases, 2018; 9: 404-409.

[DOI: https://doi.org/10.1016/j.ttbdis.2017.12.006]

13. Rubel F., Brugger K., Pfeffer M., Chitimia-Dobler L., Didyk Y.M., Leverenz S., Dautel H., Kahl O. Geographical distribution of Dermacentor marginatus and Dermacentor reticulatus in Europe. Ticks and Tick-borne Diseases, 2016; 7: 224-233.

[DOI: https://doi.org/10.1016/j.ttbdis.2015.10.015]

14. Semenyshyn O., Biletska H., Drul O. et al. Monitoring of natural foci of tick-transmissible infections in Lviv region. Sourcebook of the scientific-practical conference "Modern Problems of Epidemiology, Microbiology and Hygiene", 2010: 462-467.

\title{
ПРИРОДНІ ОСЕРЕДКИ ЛАЙМ-БОРЕЛІОЗУ У ЛЬВІВСЬКІЙ ОБЛАСТІ: РЕЗУЛЬТАТИ АКАРОЛОГІЧНИХ СПОСТЕРЕЖЕНЬ І ЛАБОРАТОРНОЇ ДІАГНОСТИКИ
}

\author{
А. М. Шульган ${ }^{1}$, О. 3. Зарічна', І. М. Лозинський', О. Б. Семенишин² \\ ${ }^{1}$ Науково-дослідний інститут епідеміології та гігієни \\ Львівського національного медичного університету імені Данила Галицького \\ вул. Зелена, 12, Львів 79005, Україна \\ ${ }^{2}$ ДУ “Львівський обласний лабораторний центр МОЗ України” \\ вул. Круп'ярська, 27, Львів 79013, Україна \\ e-mail: olha_zar@i.ua
}

Визначено спектр основних переносників збудників Лайм-бореліозу, вивчено їхню активність і епідемічне значення у природних осередках Львівської області. Беручи до уваги, що ситуація з кліщових інфекцій залежить від динаміки чисельності кліщів, проведення акарологічного моніторингу дає змогу своєчасно виявляти зміни стану природних осередків. Для території Львівської області характерне заміщення в окремих біотопах популяцій Iхоdes ricinus на Dermacentor reticulatus видом, більш толерантним до мінливих умов середовища, а загалом - зміщення меж ареалів цих двох видів. Встановлено прямий кореляційний зв'язок середньої сили між чисельністю і зараженістю кліщів I. ricinus, що підтвердило положення про те, що у природних осередках бореліозів основну роль у циркуляції збудників відіграє все ще цей вид. Середня зараженість іксодид збудником Лайм-бореліозу у Львівській області у сезон 2012-2014 рр. повністю відповідає показникам для активних природних осередків цієї інфекції. Отримано попередні дані щодо включення в коло циркуляції борелій кліщів D. marginatus, донедавна участь яких у трансмі-

ISSN 1996-4536 (print) • ISSN 2311-0783 (on-line) • Біологічні Студії / Studia Biologica • 2019 • Том 13/№1 • С. 85-94 
сії збудників Лайм-бореліозу була невідомою. Вивчення поширення й екологічних особливостей I. ricinus, D. reticulatus, D. marginatus у природних і антропогенних ценозах необхідне як для прогнозування можливого фрормування природних осередків, так і для вдосконалення стратегії і тактики протиакарицидних заходів.

Ключові слова: іксодові кліщі, Лайм-бореліоз, природні осередки

Одержано: 29.03.2019 